\title{
Characteristic of Dental and Oral Health of Bulgarian Patients with End-stage Liver Disease
}

\author{
Yordan Galabov ${ }^{1}$, Assya Krasteva ${ }^{1}$
}

1. Department Oral and Imaging diagnostics, Faculty of Dental Medicine, Medical University of Sofia, Bulgaria;

\section{Abstract}

Various pathological conditions of the liver can cause inflammation, which could lead to hepatocyte necrosis and subsequently over time to liver fibrosis, which adversely affects the overall health.

The major etiological factors for liver disease are uncontrolled alcohol intake and viral hepatitis. In the absence of drug treatment in the final stages of liver failure, liver transplantation is initiated. A large set of laboratory and clinical studies evaluate liver function and provide accurate diagnosis of liver disease and a number of medical and social conditions, determine which candidate is suitable for transplantation and when is the right time to be performed.

Dental treatment in these patients is of high priority, as different inflammatory conditions in the oral cavity can cause sepsis in patients with chronic liver failure, either pre- or post-transplant.

Keywords: dental status, oral health, patients with end-stage liver disease 


\section{Introduction}

Patients with chronic liver disease have poor oral health. There are numerous oral symptoms and findings in the oral cavity that can reflect the overall health of the patients: unprovoked gingival bleeding, petechiae, hematomas, difficulty in wound healing, glossitis and atrophic tongue, halitosis, Sjögren's syndrome, sialoadenitis, etc. Other oral changes are oral lichen planus, oral erosions and ulcers, candidiasis, angular cheilitis.

Separate studies on dental and periodontal status have also been conducted in Bulgaria on hemodialysis and renal transplant patients, as well as patients with liver disease. These reasons draw the attention of medical practitioners and dental practitioners to the oral health of patients with chronic liver disease and applicants for liver transplantation, working in multidisciplinary teams with basic tasks: successful transplantation, preventing possible complications and improving the quality of life.

\section{Aim}

The aim of the study is to determine and to give characteristics of the dental and oral health of patients with end-stage liver disease.

\section{Materials and methods}

This study includes 113 participants, divided into three groups:

\section{Group 1a}

We examined 62 patients with end-stage liver failure who are part of the list of liver transplants at the Clinic for Hepatic Pancreatic Surgery and Transplantology at the Military Hospital Sofia, representing 47.6\% of the total number of patients studied.

\section{Group 1b}

Of the patients studied, 17 underwent liver transplantation because of a sudden progression of the liver disease, $(13.07 \%$ of total patients tested)

\section{Group 2}

The control subjects were 51 (39.2\% of the total number of patients examined), selected by the Department of Imaging and Oral Diagnostics, Faculty of Dental Medicine - Sofia, without anamnesis data for systemic and common diseases. 


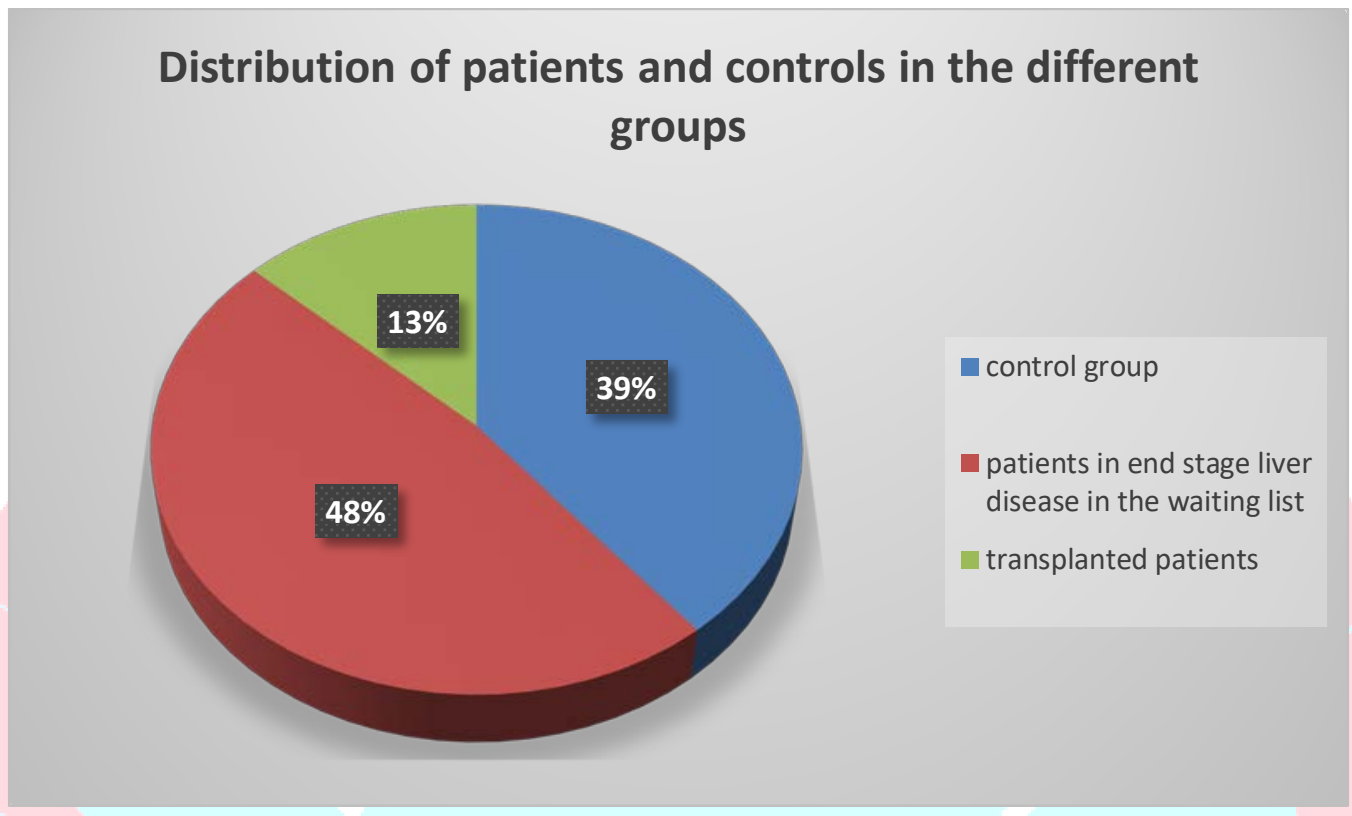

Figure 1. Distribution of patients and controls in the different groups

The criteria for inclusion of patients in the study were:

In group 1a, patients with end-stage liver failure:

1. Patients should be included in the waiting list for liver transplantation at the Clinic for Hepatic Pancreatic Surgery and Transplantation

2. Patients should not have taken NSAIDs, antibiotics, antidepressants for at least 5 days prior to the study, except for long-term treatment by a physician.

3. To examine the common unstimulated saliva or nasal in the Laboratory for Microbiology for Candida and bacterial infections

In group 1b - liver transplanted persons

1. Patients over 18 years of age.

2. With transplant more than 3 months.

In group 2 - control persons

1. Patients over 18 years of age. 
2. To be without anamnesis data on systemic and common diseases, and bad habits - regular drug intake.

3. Subjects did not take NSAIDs, antibiotics, antidepressants at least 5 days prior to the study, except for long-term treatment by a physician.

Table 1. Distribution of patients by gender and study group

\begin{tabular}{|l|c|c|c|}
\hline \multirow{3}{*}{ Gender } & \multirow{2}{*}{ Statistics } & \multicolumn{2}{|c|}{ Groups examined patients } \\
\cline { 3 - 4 } & & End stage liver disease & Control group \\
\hline \multirow{3}{*}{ Males } & Count & 43 & 18 \\
\cline { 2 - 4 } & \% & 69,4 & 35,29 \\
\hline \multirow{3}{*}{ Females } & Count & 19 & 33 \\
\cline { 2 - 4 } & Count & 30,6 & 64,7 \\
\hline \multirow{2}{*}{ Overall } & $\%$ & 62 & 100,0 \\
\cline { 2 - 4 } & & 100,0 & 51 \\
\hline
\end{tabular}

Table 2. Age characteristics of individuals in the study groups

\begin{tabular}{|l|c|c|c|c|c|}
\hline Group & $\mathbf{n}$ & $\overline{\mathrm{X}}$ & SD & Min & Max \\
\hline End stage liver disease & 62 & 43,08 & 10,92 & 14 & 61 \\
\hline Liver transplanted patients & 17 & 30,5 & 7,25 & 20 & 53 \\
\hline Control group & 51 & 39,74 & 17,84 & 18 & 75 \\
\hline
\end{tabular}




\section{Results and discussion}

Patients with end-stage liver failure had an average number of 1.7 extracted teeth, an arithmetic mean for caries lesions of 2.4 , with an average number of filled teeth 4 , and average teeth available in the mouth 20.

With regard to the available teeth, the rank ranged from 4 to 30 available teeth, the maximum of carious lesions was 7 , and of the obturations 8 .

Our group of patients is characterized by one or three carieses and twice a rare 2 or 4 carieses. Up to 3 caries have $2 / 3$ of patients.

We believe that we must attribute carious lesions to the real dentition. Most often, patients have 26 teeth with 1-3 caries or about 10 teeth with 1 carious lesion. Only $11 \%$ of patients lacked carious lesions. Comparing the data with a similar population of patients Panov (1) found carious lesions in $21 \%$ of patients with chronic hepatitis, a lower incidence than us. A slightly lower frequency, reports P. Barbero.(2) P. Barbero et al. found a very high percentage of patients for transplantation with broken teeth as a result of a carious process (76\%), with $20 \%$ having periapical changes.

\section{Obturations in patients with end-stage liver failure}

In the group of patients studied between $4-5$ obturations have about $40 \%$ of patients. The proportion of patients with more than 5 obturations is high - over $25 \%$. On average, there are 1 obturations per 4 available teeth. VI.Panov establishes obturations in $61 \%$ of patients with chronic hepatitis, and in those with the largest share was occupied by persons with more than 6 obturated teeth. Patients with 2 to 4 and 4 to 6 represented $17 \%$ each, missing patients with 1 obturation (1).

\section{Missing teeth in patients with end-stage liver failure}

It is noteworthy that dental extractions were not performed in $27 \%$ of patients. The highest proportion of patients with 1 extraction is $-23 \%$. In total, the group of $1-3$ extractions represents about $60 \%$ of patients. Only 9 are patients with $4-5$ extracted teeth $-14 \%$

Vl. Panov, in his study, has documented that patients with chronic hepatitis document that only $10 \%$ are without extracted teeth. His data shows that $35 \%$ of patients have up to 4 extractions (1), our data indicate twice as high incidence of lost teeth.

If we compare our data on end-stage liver failure with Bulgarian patients with chronic viral hepatitis (1), we can see in the first place - the difference in age of those with chronic hepatitis is 55 years and age change in dental status can be expected. The incidence of carious lesions in our country is twice as high $-2.4 \pm 3$ 1.76 versus $1.26 \pm 3.82$ in non-severe liver disease. The same can happen for more frequent obturations in our group the median is 4.5 and in the less ill 2.5. 
Residual roots in patients with end-stage liver failure

Residual roots were present in 25 patients, representing $41 \%$ of the group. In the control group, only five patients had residual roots in the oral cavity - representing $9.8 \%$ of the entire group.

Fixed prosthodontics in patients in end-stage liver failure

Regarding the number of prosthetic restorations, no significant difference was found between the patients and controls, with the average number of fixed prosthetic restorations for the group being 3 , with the median and the mean arithmetic coinciding.

\section{Nicotine and alcohol use in patients with end-stage liver failure}

In our patients, the proportion of persons with alcoholic hepatitis and viral hepatitis was almost equal - about $35 \%$. Followed by $18 \%$ etiological factor hepatitis $C$ and $11 \%$ autoimmune diseases of the liver.

V. Mihailov in his study "Liver Transplantation - Surgical Approach and Results" reported an incidence of alcoholic hepatitis of $34 \%$, followed by viral hepatitis in $30 \%$. The percentages of the two studies are similar, since the subject is the same contingent of patients (3). The author finds that in $4 \%$ of his patients, cirrhosis is a combination of alcohol and hepatitis $B$, and with the years the proportion of patients with viral and other etiology increases over time at the expense of alcohol reduction as a cause of transplantation (3).

In the controls, approximately $15 \%$ of the subjects reported regular consumption of alcoholic beverages.

We found a statistically significant difference between mean nicotine use in patients with end-stage liver failure and controls, with significantly more frequent consumption in patients with liver disease.

It is evident that the majority of these patients consume nicotine - $60 \%$, which is one of the preconditions to expect changes in the dental and oral status of patients. For comparison, the proportion of smokers in the control group is $44 \%$.

Of the patients, persons with alcoholic hepatitis represent about $35 \%$ of patients. Data in the medical literature indicate frequent concomitant abuse of nicotine and alcohol in liver patients $(3,4)$.

\section{Metabolic disorders in patients with end-stage liver failure}

One fifth of patients with severe liver disease have proven diabetes mellitus. Marinova's studies of metabolic markers in chronic liver disease - 2014 show serious metabolic abnormalities in liver patients: higher glucose and insulin levels, much higher NOMA in patients with alcohol and non-alcoholic, insulin utilization. Cholesterol and triglycerides are also higher. The other significant deficiency is that of vitamin $\mathrm{D}$, which in cirrhosis is twice lower compared to previous stages of liver disease (4).

Dry mouth in patients with end-stage liver failure 
There is a high percentage of those reporting xerostomia - 47\%. The drug therapy of these patients receiving diuretics due to the presence of ascites, and some of them with diabetes, should also be considered. Oral complications in people with diabetes include: xerostomia (dry mouth), inflammation of soft tissues such as gingivitis, parodontitis, difficult to heal wounds after surgery in the oral cavity. In poorly controlled diabetes, the risk of problems in the oral cavity is increased due to impaired leukocyte function, impaired blood flow, etc. Smokers with diabetes are 20 times more likely to develop periodontal and fungal disorders than nonsmokers (5).

The sensation of dryness in the oral cavity understandably causes serious discomfort to patients. Subjective complaint is both drug-induced by both immunosuppressive therapy and antihypertensive therapy (6)

Valentensin belongs to a group of medicines called angiotensin II receptor blockers and is mentioned in the leaflet as a side effect of mouth irritation. $18 \%$ of our patients are on this therapy.

Spironolactone is a potassium-sparing diuretic, a medicine that increases urine output, also causing xerostomia, and is taken by $13 \%$ of patients.

In comparison with the control group of dry mouth, 8 patients complained of representing $15.7 \%$ and using the non-parametric methods of analysis proved that the difference between the two groups is statistically significant.

\section{Dysphagia and dysgeusia in patients with end-stage liver failure}

$23 \%$ of patients complained of swallowing pain, and $32 \%$ of altered taste.

In the control group with subjective symptoms, $5.9 \%$ had swallowing pain and $21 \%$ reported altered taste in the mouth.

Analyzing the subjective symptom of dysphagia between controls and patients, we found a statistically significant difference.

There was no statistically significant difference in the subjective complaint of altered taste in the oral cavity between patients and controls.

\section{Parodontal status in patients with end-stage liver failure}

Thirteen studies, published between 1981 and 2014, were found to include data on oral health and periodontal disease in patients with cirrhosis. Studies have shown an increased incidence of chronic parodontitis in patients with cirrhosis of the liver, measured by several different parodontal indicators. Parodontitis is diagnosed in $25.0 \%$ to $68.75 \%$ of patients with cirrhosis (7). Our data indicate a systemically high incidence of chronic parodontal disease - 91.9\%. Parodontitis is present in almost all patients with endstage liver failure. DPSI in 2/3 of patients has a value of 2 and less often an index of 3. 
Oral lichen planus in patients with end-stage renal disease

Lichen planus (lichen planus) is an autoimmune inflammatory disease, with $50 \%$ of patients presenting with mucosal lesions and $23 \%$ with oral ones only (8). K. P. Kyriakis et al. find that 0.3 to $0.8 \%$ of the world's population suffers from various forms of oral lichen (9).

Our data indicate a 10 times higher incidence of oral lichen in patients with hepatic impairment. This higher frequency may be associated with medication intake and drug-induced forms of lichen planus (6).

Petechial lesions in oral mucosa in patients with end-stage liver failure

The liver synthesizes many of the blood clotting factors required for hemostasis. The following orofacial manifestations are expected in patients with liver disease: petechiae or excessive bleeding from the oral mucosa after mild trauma. The condition is especially suspicious in the absence of an inflammatory component in the mouth. Therefore, dental manipulations should be performed with particular care because of the real risk of severe hemorrhage as a result of insufficient blood clotting factors (10).

Of our patients with petechial lesions in the oral cavity were 20 individuals.

Cheilitis in patients with end-stage liver failure

In patients with hepatic cirrhosis, raspberry (lacquered) lips, red and smooth tongue, vascular stars on the neck, face are expected (they look like a spider and disappear when pressed) (10). There were 15 patients with cheilitis.

\section{Bacterial and fungal infection in the oral cavity in patients with end-stage liver transplantation}

It is recommended that patients be examined by a dentist before organ transplantation, as untreated oral diseases (including dental problems) can cause infections and sepsis and lead to a number of complications in transplant patients (11).

Bacterial sepsis has been cited in the medical literature as a major cause of death for these patients during the first postoperative month. The risk of infection increases significantly as a result of massive immunosuppressive therapy, and dentists must be prepared to deal with the profuse bleeding provoked by liver dysfunction (2).

One third of the patients have candida infection and staphylococcus infection.

When preparing a plan for the rehabilitation of patients, targeted therapy for antibiotic or antimycotic treatment was prescribed according to the antibiogram and in accordance with their general condition. 
The appearance of candidiasis plaques is associated with: antibiotic intake; administration of corticosteroids (including inhalers used to control asthma); diabetes; leukemia; malignancies; immunosuppressive therapy; immunodeficiency diseases; anemia (12).

\section{Conclusion}

\section{Concerning the dental status of patients with end-stage liver failure.}

1. Dental status places transplanted patients between patients in end-stage liver disease and control subjects.

2. Patients with end-stage liver disease have the worst dental status damage - the highest number of carious lesions and more often have residual roots.

\section{Concerning the oral health of patients with end - stage liver failure.}

1. Patients with end-stage liver failure have poor oral health - with moderate to severe periodontitis, higher use of nicotine products, higher incidence of xerostomia, dysphagia, relative to the control group.

2. The percentage of patients with staphylococcal and candida infection is almost the same- around $32 \%$.

3. Oral lesions diagnosed in patients are: petechial lesions (32.3\%), cheilitis $(24.2 \%)$, gingival hyperplasia $(14.5 \%)$, yellowish pigmentation of the oral mucosa $(9.7 \%)$, oral lichenoid lesions (8.1\%), erosive lesions (4.8\%).

Dental treatment of liver patients before transplantation and removal of all potential foci of infection are a required routine procedure from specialized centers for the treatment of end stage liver disease patients worldwide. There are no specific protocols for the diagnosis and treatment of oral and dental diseases of this group of patients in our country and building such for this contingent of patients is necessary.

It is important to characterize the dental status of end-stage liver failure patients, to evaluate their oral health, to be analyzed the need of medications application.

\section{References}

1. Панов, Вл. Устната кухина - биосистема и възможен източник на инфекциозен материал. Канд.дисерт. Варна 2010

2. Barbero, P., M. Garzino Demo, M. Milanesio, A. Ottobrelli. The dental assessment of the patient waiting for a liver transplant. Minerva Stomatol, 45, 1996: 431-439.

3. Михайлов В. Чернодорбна трансплантация - хирургичен подход и резултати. дисертационен труд за присъждане на образователната и научна степен "докторпо медицина" София 2015; 218 стр 
4. Джемилева, Т. В: Заболявания на пародонта. Ацер. София, 1999, 367 стр.

5. Кръстева, А. Лекарствена непоносимост и оралните й прояви. - В : Алергология и орална медицина: принципи и практики, София: Ив. Сапунджиев - ЕООД, 2013, 109-132.

6. Grønkjær L. Periodontal disease and liver cirrhosis: A systematic review SAGE Open Med. 2015; 3: 2050312115601122.

7. Угринов, Р., К. Георгиева, П. Кавлаков и съавт. Лицево-челюстна и орална хирургия. Тумори на устната кухина, лицево-челюстната и шийна области. Издателство „Киви”, С., 2006: 484-516.

8. Kyriakis, K., S. Terzoudi, I. Palamaras et al. Sex and age distribution of patients with lichen planus. J Eur Acad Dermatol Venereol, 20, 2006: 625-626.

9. Панов Вл., А. Кръстева, А. Киселова в Орални лезии. Орални прояви на общи заболявания и лекарствено индуцирани състояния. Под ред. на проф. 3. Кръстев. София: Ив. Сапунджиев - ЕООД, 2011. ISBN 978-954-9971-52-1. - 3

10. Guggenheimer, J., B. Eghtesad, J. Close, C. Shay, J. Fung. Dental health status of liver transplant candidates. Liver Transpl, 13, 2007: 280-286.

11. Кръстева, А. Орални лезии и клиничната медицина, под редакцията на проф.3. Кръстев, София , 2018г. Издателство Мединформ - ЕООД, 2018 ISBN 978-619-7164-11-4.

\section{Corresponding author:}

Yordan Galabov,

Faculty of Dental Medicine,

Department of Oral and Imaging Diagnostic,

1 Sveti Georgi Sofiiski str.,

1431 Sofia, Bulgaria,

email: j.galabov@gmail.com 